\title{
Pengelolaan Media Sosial Instagram sebagai Media Komunikasi PT Patra Bangun Properti
}

\author{
Muhammad Rafi Pradana ${ }^{1}$, Hanny Hafiar ${ }^{2}$, Heru Ryanto Budiana ${ }^{3}$ \\ 1,2 Universitas Padjajaran, Indonesia. mrafipradana98@gmail.com \\ Management of Instagram Social Media as a Communication Media of \\ PT Patra Bangun Properti
}

\begin{abstract}
This research is a descriptive study that focuses on knowing the stages of Instagram social media management that done by PT Patra Bangun Properti as a communication media using the ROSTIR concept. Data collection techniques using interviews with eight informants, observation, literature study, and documentation. The data validity technique uses source triangulation. The results of the study state that 1) Research and diagnosis has been carried out by PT Patra Bangun Properti by conducting primary research using observations and interviews, secondary research by analyzing personal data, and SWOT analysis on social media instagram, 2) the goals set by PT Patra Bangun Properti can achieved and devoted 3) The strategy used by PT Patra Bangun Properti is to establish Instagram as a specific channel used and to use key messages 4) PT Patra Bangun Properti uses Paid Media tactics, namely advertisements on Instagram, Earned Media relies on the involvement of netizens, and Owned media although Instagram's social media is not fully controlled by PT Patra Bangun Properti. 5) Implementation of PT Patra Bangun Properti is by uploading content on Instagram social media, PT Patra Bangun Properti incurred costs in managing social media, as well as the Instagram timeline consisting of photos and videos, 6) PT Patra Bangun Properti conducts reports and evaluations only on the end of the activity.
\end{abstract}

Keywords: management, social media, ROSTIR, instagram

\begin{abstract}
ABSTRAK
Penelitian ini merupakan penelitian deskriptif yang berfokus unuk mengetahui tahapan pengelolaan media sosial Instagram yang dilakukan oleh PT Patra Bangun Properti sebagai media komunikasi dengan menggunakan konsep ROSTIR. Teknik pengumpulan data menggunakan Wawancara dengan delapan informan, Observasi, Studi Pustaka, dan Dokumentasi. Teknik validitas data menggunakan triangulasi sumber. Hasil penelitian menyebutkan bahwa 1) Riset dan diagnosis telah dilakukan oleh PT Patra Bangun Properti dengan melakukan riset primer menggunakan observasi dan wawancara, riset sekunder dengan menganalisis data pribadi, serta analisis SWOT pada media sosial instagram, 2) tujuan yang ditetapkan PT Patra Bangun Properti dapat dicapai dan diwaktukan 3) Strategi yang digunakan PT Patra Bangun Properti adalah menetapkan instagram sebagai saluran spesifik yang digunakan dan menggunakan pesan kunci 4) PT Patra Bangun Properti menggunakan taktik Paid Media yaitu dengan iklan yang ada di instagram, Earned Media dengan mengandalkan keterlibatan netizen, serta Owned media walaupun sosial media instagram ini tidak sepenuhnya dikendalikan oleh PT Patra Bangun Properti. 5) Implementasi PT Patra Bangun Properti adalah dengan mengunggah konten konten pada media sosial instagram, PT Patra Bangun Properti mengeluarkan biaya dalam pengelolaan media sosial, serta linimasa instagram yang terdiri dari foto dan video, 6) PT Patra Bangun Properti melakukan laporan dan evaluasi hanya pada akhir pelaksanaan kegiatan.
\end{abstract}

Kata Kunci: pengelolaan, media sosial, ROSTIR, instagram 


\section{PENDAHULUAN}

PT Patra Bangun Properti merupakan salah satu perusahaan yang menggunakan instagram dengan nama akun @padinaofficial sebagai media komunikasi untuk dapat berinteraksi kepada pelanggan ataupun pengikut dari media sosial Instagram PT Patra Bangun Properti.

Aktifnya PT Patra Bangun Properti menggunakan instagram ini dapat dilihat dari media sosial instagram @padinaofficial itu sendiri, dibandingkan dengan kompetitornya yang dimana memiliki produk yang sama yaitu apartemen dan berada di dalam satu daerah yaitu Daan Mogot, PT Patra Bangun Properti dapat dibilang lebih unggul dari segi media sosial instagram apabila dibandingkan dengan kompetitornya. Dapat dikatakan lebih unggul dari segi media sosial dikarenakan jumlah pengikut, jumlah unggahan dari akun instagram @padinaofficial lebih banyak dibandingkan dengan kompetitornya yaitu @apartemengreenparkview dan @daanmogotcity_cccg.

PT Patra Bangun Properti (PBP) sendiri merupakan perusahaan yang bergerak dibidang pembangunan properti yang merupakan anak usaha dari PT Patra Dinamika (PADI) yang sudah bergerak dibidang underwater service selama 20 tahun lebih. Tentunya dengan pengalaman perusahaan seperti itu menjadikan PADI bergerak dibidang lain yaitu Properti dikarenakan melihat prospek bisnis properti yang menjanjikan sehingga menciptakan anak usaha baru yaitu PT Patra Bangun Properti. PBP ini memiliki produk yang bernama Padina $\mathrm{SOHO}$ and Residence yang dimana masih dalam proses pembangunan dan sudah mencapai 80 persen.

Mohammad Arsyad Lubis selaku Direktur Utama PT Patra Bangun Properti mengatakan bahwa mereka menggunakan media sosial instagram dikarenakan instagram mampu mencapai audiens lebih jauh serta dapat membantu mereka dalam berkomunikasi dengan audiens atau netizen. Selain itu pak Arsyad juga mengatakan bahwa langkah pertama mereka dalam menggunakan media sosial instagram tersebut adalah merundingkan dan mendiskusikan konten apa yang akan dimuat di instagram nanti. Pak Arsyad juga mengatakan bahwa dalam menggunakan instagram tersebut mereka menggunakan iklan untuk mencapai audiens yang lebih luas serta audiens yang sudah ditargetkan seperti profesi yang berhubungan dengan aviasi dikarenakan produk yang disediakan atau ditawarkan ini dekat dengan bandara, serta mereka mengeluarkan biaya yang berbeda beda sesuai dengan kebutuhan iklan.

Selain itu, mereka melakukan evaluasi hanya pada waktu tertentu yang biasanya dilakukan hanya sebulan sekali dan berfokus kepada pelayanan serta meningkatnya penjualan mereka dengan menggunakan media sosial instagram.

Oleh sebab itu peneliti tertarik untuk meneliti lebih lanjut mengenai tahapan tahapan pengelolaan media sosial yaitu ROSTIR yang dikemukakan oleh Regina Luttrell (2018) dengan pengelolaan media sosial instagram PT Patra Bangun Properti sebagai media komunikasi.

Penelitian ini bertujuan untuk (1) mengetahui riset dan diagnosis yang dilakukan dalam pengelolaan media sosial oleh PT Patra Bangun Properti, (2) mengetahui penetapan objektif dalam pengelolaan media sosial instagram PT Patra Bangun Properti, (3) mengetahui 
strategi yang digunakan dalam pengelolaan media sosial instagram PT Patra Bangun Properti, (4) mengetahui taktik yang dilaksanakan dalam pengelolaan media sosial instagram PT Patra Bangun Properti, (5) mengetahui implementasi, biaya dan linimasa dalam pengelolaan media sosial instagram PT Patra Bangun Properti, (6) mengetahui laporan dan evaluasi yang dilakukan dalam pengelolaan media sosial instagram PT Patra Bangun Properti.

Berdasarkan Luttrell (2018) ROSTIR merupakan tahapan yang terdiri dari (1) Research and Diagnosis, (2) Objectives, (3) Strategy, (4) Tactics, (5) Implementation, Budget, and Timeline, (6) Report and Evaluation yang pada setiap tahapnya tersebut berkontribusi dalam perencanaan atau pengelolaan media sosial yang pada dasarnya hal ini merupakan kelanjutan dari tahapan atau proses SoMe yang dikemukakan oleh Regina Luttrell.

Tahapan pertama yaitu riset dan diagnosis. Tahapan ini adalah tahapan pertama yang dilakukan dalam tahapan ROSTIR dan berdasarkan Luttrell (2018:112) bahwa riset dan diagnosis terdiri dari (1) riset primer, (2) riset sekunder dan (3) analisis SWOT yang bertujuan untuk mengetahui dan membantu menentukan segmen media sosial.

Tahapan kedua yaitu objektif atau tujuan. Pada tahapan ini adalah dimana tujuan untuk pengelolaan media sosial ini ditetapkan dan berdasarkan Luttrell (2018:115) bahwa tujuan atau objektif ini dideskripsikan atau dituangkan dalam model SMART yang merupakan singkatan dari (1) specific, (2) measurable, (3) attainable, (4) relevant, (5) timely.

Tahapan ketiga yaitu strategi. Pada tahapan strategi ini adalah dimana strategi yang dipilih untuk digunakan berdasarkan pertimbangan tersebut akan ditetapkan. Dalam hal ini berdasarkan Luttrell (2018:116) bahwa dalam tahapan strategi ini terdiri dari (1) saluran spesifik dan (2) pesan kunci.

Tahapan keempat adalah taktik. Pada tahapan taktik ini adalah dimana untuk menentukan taktik yang digunakan dalam pengelolaan media sosial dan berdasarkan Luttrell (2018:118) bahwa taktik yang digunakan dapat dijelaskan dengan model PESO yaitu (1) Paid media, (2) Earned Media, (3) Shared Media, (4) Owned Media yang dimana nantinya modeltersebut akan membantu menjelaskan taktik yang digunakan dalam pengelolaan media sosial tersebut.

Tahapan kelima adalah implementasi, biaya dan linimasa. Berdasarkan Luttrell (2018:123) bahwa tahapan ini adalah tahapan penerapan semua taktik atau strategi yang telah ditetapkan atau driancang sebelumnya dan tahapan ini terdiri dari (1) implementasi, (2) biaya, (3) linimasa. Pada tahapan ini bertujuan untuk melihat penerapan strategi yang dilakukan, biaya yang dikeluarkan serta linimasa media sosial.

Tahapan terakhir adalah laporan dan evaluasi. Berdasarkan Luttrell (2018:124) bahwa tahapan laporan dan evaluasi terdiri (1) laporan dan (2) evaluasi yang dimana bertujuan untuk melihat hasil juga untuk menilai yang telah dilakukan dengan dilakukannya laporan dan evaluasi pada setiap tahapan yang ditujukan.

\section{METODE}

Penelitian ini merupakan penelitian kualitatif dan bersifat deskriptif, yaitu penelitian yang bertujuan menggambarkan dan menelaah permasalahan yang ada pada masa sekarang. 
Penelitian kualitatif adalah penelitian yang bermaksud untuk memahami fenomena tentang apa yang dialami oleh subjek penelitian secara holistik dan dengan cara deskripsi dalam bentuk kata-kata dan bahasa, pada suatu konteks khusus yang alamiah dan dengan memanfaatkan berbagai metode ilmiah (Moleong: 2007). Pada penelitian ini, pengelolaan media sosial instagram menjadi fokus penelitian dimana peneliti berusaha untuk melihat atau menemukan apakah pengelolaan media sosial PT Patra Bangun Properti ini telah sesuai dengan tahapan ROSTIR yang dikemukakan oleh Regina Luttrell.

Informan yang dipilih oleh peneliti adalah: (1) Mohammad Arsyad Lubis selaku Direktur Utama PT Patra Bangun Properti, (2) Achmad Daylami selaku HR\&GA PT Patra Bangun Properti, (3) Esti Sulistya Sari selaku GM Marketing PT Patra Bangun Properti, (4) Veronica Louw selaku CEO PT Nata Connexindo Digital, (5) Steven Samuel selaku Digital Marketing Consultant PT Nata Connexindo Digital, (6) Teddy Kartiawan Syahnugrah selaku Digital Marketing Consultant PT Nata Connexindo Digital Manager, (7) Sylva Trivena selaku Digital Marketing Consultant PT Nata Connexindo Digital, (8) Aminah selaku Digital Marketing Consultant PT Nata Connexindo Digital.

Peneliti menggunakan non-probability sampling yang dimana pemilihan sampel tidak melihat ketentuan ketentuan atau prinsip prinsip probabilitas. Peneliti menggunakan jenis purposive sampling atau judgment sampling dikarenakan peneliti telah mempertimbangkan dan menganggap bahwa sampel yang ditunjuk atau ditentukan oleh peneliti dapat memberikan informasi yang akurat bagi penelitian yang dilakukan.

Dalam penelitian ini, peneliti menggunakan (1) Observasi, (2) Wawancara, (3) Studi Pustaka dan (4) Dokumentasi. Adapun bentuk observasi yang digunakan dalam penelitian ini adalah observasi pasif, dimana peneliti hanya bertindak sebagai pengumpul data, mencatat kegiatan yang sedang berjalan. Dalam observasi ini peneliti hanya mengamati tetapi tidak ikut serta dalam semua aktivitas tersebut (Sugiyono, 2010:62)

Peneliti melakukan wawancara terstruktur yang dimana peneliti melakukan atau menanyakan pertanyaan kepada informan berdasarkan pedoman wawancara yang telah dibuat sebelumnya. Hal ini ditujukan untuk mencegah kesalahan informasi yang didapat oleh peneliti dalam mencari data.

Selain memperoleh data dengan cara observasi serta wawancara, peneliti juga memperoleh data atau fakta dari profil perusahaan atau company profile milik PT Patra Bangun Properti dan media sosial instagram PT Patra Bangun Properti itu sendiri serta situs maupun beberapa laporan mengenai media sosial PT Patra Bangun Properti.

Sementara itu, keabsahan data pada penelitian ini dilakukan metode triangulasi. Triangulasi dalam pengujian kredibilitas diartikan sebagai pengecekan data dari berbagai sumber dengan berbagai waktu. Menurut (Sugiyono, 2012: 270) uji keabsahan data dalam penelitian kualitatif adalah untuk menguji, credibility, transferability, dependability, dan confirmability pada data yang telah diperoleh. Peneliti menggunakan triangulasi sumber dalam penelitian ini. Triangulasi sumber dilakukan kepada Nur-El Ikhsan yaitu seorang dosen Marketing dan Manajemen di Institut IImu Sosial dan Manajemen STIAMI 


\section{HASIL DAN PEMBAHASAN}

Pengelolaan media sosial tentunya memiliki peranan penting bagi perusahaan dikarenakan menurut Eisenberg (dalam Pakuningjati 2015:6) menyimpulkan bahwa media sosial dalam definisi yang lebih efektif adalah sebagai platform online untuk berinteraksi, berkolaborasi, dan menciptakan atau membagi berbagai macam konten digital. Maka dari itu PT Patra Bangun Properti melakukan pengelolaan media sosial instagram.

Riset dan diagnosis itu sendiri terdiri dari tiga poin yaitu riset primer, riset sekunder, serta analisis SWOT.

\section{Model 1 Riset Primer}

Berdasarkan pernyataan dari Kriyantono (2014:41) bahwa riset primer adalah riset dengan menggunakan metode kuisioner, wawancara dan observasi yang bertujuan untuk mendapatkan data secara primer atau data dari sumber pertama.

Riset primer yang dilakukan oleh PT Patra Bangun Properti dalam kegiatan pengelolaan media sosial ini dapat dikatakan belum maksimal dikarenakan pada proses riset primer yang dilakukan oleh PT Patra Bangun Properti ini tidak menggunakan kuisioner dalam mengumpulkan data secara primer.

Menurut Pujihastuti (2010:44) bahwa kuesioner membantu untuk mendapatkan data mengenai sikap, opini, harapan serta keinginan yang dimiliki oleh responden. Hal ini juga didukung oleh pendapat Anwar (2009:168) bahwa kuisioner merupakan sejumlah pernyataan yang diajukan kepada responden mengenai data faktual atau opini yang berkaitan pada diri responden. Maka dari itu sebaiknya PT Patra Bangun Properti menggunakan kuisioner dalam melakukan riset primer.

\section{Model 2 Riset Sekunder}

Menurut Kriyantono (2014:42) data sekunder adalah data yang diperoleh dari sumber kedua atau sumber sekunder yang dimana data sekunder ini merupakan data primer yang telah diolah menjadi lebih lanjut menjadi table, grafik, diagram dan gambar. Hal ini juga didukung oleh Umar (2013:42) bahwa data sekunder dalah data primer yang telah diolah lebih lanjut dan disajikan dalam bentuk table atau diagram. Sehingga dapat dikatakan bahwa riset sekunder adalah riset yang menggunakan table, grafik, diagram dan gambar yang bertujuan untuk mendapatkan data dari sumber kedua atau data sekunder.

Dalam hal ini, PT Patra Bangun Properti sudah melakukan riset sekunder secara maksimal dan tepat dikarenakan mereka melakukan riset dengan cara menganalisis data yang berbentuk table, grafik, diagram, dan gambar. Menurut Kriyantono (2014:42), periset harus lebih selektif atau lebih berhati hati dalam memilih dan menggunakan data sekunder, dalam hal untuk meningkatkan kegiatan riset sekunder yang dilakukan oleh PT Patra Bangun Properti adalah lebih selektif atau lebih memilih data sekunder yang akan digunakan dalam proses riset sekunder tersebut yang bertujuan untuk melengkapi data primer yang diperoleh dengan riset primer. Selain dalam bentuk table, diagram, grafik dan gambar yang sudah di seleksi, menurut Sekaran (2011) bahwa sumber data yang diperoleh melalui riset sekunder 
dapat diperoleh melalui catatan atau dokumentasi perusahaan, publikasi milik pemerintah, analisis industry oleh media, situs web dan seterusnya.

\section{Model 3 Analisis SWOT}

Menurut Fahmi (2013:260), dalam menganalisis SWOT perlu dilihat faktor internal dan eksternal perusahaan yang dimana mempengaruhi pengambilan keputusan perusahaan. Faktor eksternal ini mempengaruhi terbentuknya opportunities and threats (O dan T). Dimana faktor ini menyangkut dengan kondisi-kondisi yang terjadi di luar perusahaan yang mempengaruhi dalam pembuatan keputusan perusahaan. Faktor ini mencakup lingkungan industri dan lingkungan bisnis makro, ekonomi, politik, hukum, teknologi, kependudukan, dan sosial budaya.

Sementara itu, Faktor internal mempengaruhi terbentuknya strengths and weaknesses (S dan W). Dimana faktor ini menyangkut dengan kondisi yang terjadi dalam perusahaan, yang mana ini turut mempengaruhi terbentuknya pembuatan keputusan perusahaan. Pada faktor internal ini terdapat semua macam manajemen fungsional seperti pemasaran, keuangan, operasi, sumberdaya manusia, penelitian dan pengembangan, system informasi manajemen dan budaya perusahaan (corporate culture).

Dalam hal ini, PT Patra Bangun Properti melakukan analisis SWOT hanya saja analisis SWOT yang dilakukan kuranglah mendalam dikarenakan analisis pada faktor internal yaitu Strength dan Weakness yang masih belum mendalam yang dimana hal ini dapat dilihat dari analisis strength dan weakness pada media sosial milik PT Patra Bangun Properti yang hanya memperhatikan faktor pemasaran, sumberdaya manusia, dan sistem informasi manajemen. Tentunya hal ini juga berpengaruh pada analisis faktor eksternal yaitu Opportunity dan Threat yang dimana hal ini dapat dilihat pada analisis mengenai opportunity dan threat pada media sosial milik PBP yang hanya memperhatikan faktor lingkungan bisnis makro dan lingkungan industri, teknologi.

Sementara itu, kegunaan atau fungsi dari analisis SWOT Menurut Ferrel dan Harline (2005) itu sendiri yaitu untuk mendapatkan informasi dari analisis situasi dan memisahkannya dalam persoalan internal (Strength dan Weakness) dan persoalan eksternal (Opportunity dan Threat). Sementara itu menurut MindTools (Dalam Luttrell, 2018: 113) bahwa SWOT dapat membuka atau memperlihatkan kesempatan yang ditempatkan dengan baik, serta dapat membantu mengatur atau menghilangkan ancaman apabila mengerti kelemahan yang dimiliki. Apabila analisis SWOT yang dilakukan kurang mendalam pada persoalan internal maupun eksternal, tentunya berdampak pada tidak menemukan atau melihat kesempatan yang ada, dan tidak mengerti kelemahan yang dimiliki. Maka dari itu, sebaiknya PT Patra Bangun Properti melakukan analisis SWOT secara mendalam dengan lebih memperhatikan beberapa pada faktor internal dan eksternal.

Setelah tahapan riset dan diagnosis yang dilakukan oleh PT Patra Bangun Properti dalam pengelolaan media sosial, tahapan selanjutnya adalah tujuan yang dimana berdasarkan Luttrell bahwa tujuan atau objektif ini dijabarkan atau dijelaskan dalam model SMART. 


\section{Model 4 Tujuan Spesifik}

Dalam hal ini, tujuan spesifik menurut Doran (1981) adalah menargetkan area yang spesifik untuk ditingkatkan. Sejalan dengan Poister (2008:63) juga mengemukakan bahwa spesifik yang dimaksud adalah dengan menargetkan area yang spesifik untuk ditingkatkan, dalam hal ini PT Patra Bangun Properti memiliki tujuan spesifik yaitu menjadikan media sosial yang digunakan ini untuk membantu penjualan serta menjadi media sosial untuk berkomunikasi. Apabila dilihat kembali, tujuan PT Patra Bangun Properti tidak menandakan area yang spesifik untuk ditingkatkan dikarenakan mereka memiliki dua tujuan utama yang apabila dilihat adalah dua hal utama untuk ditingkatkan.

Menurut Doran (1981) , Dwyer dan Hopwood (2010) apabila PT Patra Bangun Properti tidak menargetkan area yang spesifik dalam tujuan spesifik yang telah ditetapkan dan tidak menyampaikan secara rinci apa yang ingin dicapai serta tujuan tersebut masih membingungkan. Maka dari itu sebaiknya PT Patra Bangun Properti menargetkan area spesifik untuk ditingkatkan serta merincikan apa yang ingin dicapai secara spesifik.

Selanjutnya adalah dapat diukur atau measurable.

\section{Model 5 Tujuan yang dapat Diukur}

Menurut Doran (1981) tujuan yang dapat diukur berarti menghitung atau setidaknya memiliki, mempunyai indikator dalam proses yang dijalankan. PT Patra Bangun Properti memiliki tujuan yang dapat diukur dari pengelolaan media sosial ini yaitu "meningkatnya awareness yang dimana nantinya akan berakibat pada meningkatnya penjualan melalui media sosial yang digunakan". Namun berdasarkan hasil wawancara mereka, mereka tidak menyebutkan adanya indikator untuk menghitung peningkatan awareness atau mereka tidak mengatakan adanya indikator untuk mengukur setiap proses yang telah mereka capai yang dimana indikator tersebut merupakan hal penting dalam mengukur apakah tujuan yang sudah mereka tetapkan sebelumnya dilihat dari indikator yang ditetapkan.

Apabila dilihat berdasarkan Doran (1981) dan Richman (2011:65) jika mereka tidak memiliki indikator untuk mengukur tujuan yang sudah ditetapkan tentunya akan berdampak pada kesulitan dalam mengukur tujuan yang sudah ditetapkan tersebut dikarenakan tidak memiliki indikator untuk menandai sudah sejauh mana kemajuan atau tujuan yang dicapai dalam pengelolaan media sosial PT Patra Bangun Properti. Selain itu menurut Yemm (2013:37-39) bahwa beberapa tujuan dapat diukur secara mudah dikarenakan mereka dapat diukur dan menggunakan nomor dan persentase yang hasilnya dapat mudah ditemukan. Maka dari itu PT Patra Bangun Properti harus memiliki indikator dalam atau untuk mengukur tujuan tujuan yang akan dicapai atau yang sudah dicapai sehingga mudah untuk melihat dan menilai tujuan yang sudah dicapai dan tujuan yang belum dicapai.

\section{Model 6 Tujuan yang dapat Dicapai}

Menurut O'Neil dan Conzemius (2006:33), bahwa tujuan yang dapat dicapai adalah tujuan yang ditetapkan ini merupakan hal yang harus dapat dicapai oleh perusahaan, maka 
dari itu pembuatan tujuan yang dapat dicapai tersebut harus tidak terlalu mudah dan tidak terlalu sulit dikarenakan apabila terlalu mudah maka perusahaan tidak akan termotivasi. PT Patra Bangun Properti memiliki tujuan yaitu mendapatkan pengikut sebanyak banyaknya serta menjual unit apartemen sebanyak banyaknya.

Berdasarkan Yemm (2013:37-39), Dwyer dan Hopwood (2010) tujuan yang sudah ditetapkan tersebut adalah tujuan yang paling memungkinkan untuk dicapai dikarenakan hal tersebut adalah hal yang paling memungkinkan dikarenakan PT Patra Bangun Properti berpendapat bahwa tujuan tersebut dapat dicapai, hal ini juga didukung oleh Lawler dan Bilson (2013:85) yang mengatakan bahwa tujuan yang ditetapkan haruslah dapat dicapai oleh perusahaan. Hal ini didukung oleh pernyataan Frey dan Osterloh (2002:234) yang mengatakan bahwa tujuan yang dapat dicapai tersebut ditetapkan berdasarkan standar dari pekerjaan mereka. Dapat dilihat bahwa tujuan yang dapat dicapai tersebut dapat dicapai oleh PT Patra Bangun Properti dan berdasarkan O’Neil dan Conzemius (2006:33) bahwa untuk tetap memperhitungkan focus, energy, waktu dan sumber daya yang digunakan sehingga tujuan yang telah ditetapkan tersebut dapat tercapai. Maka dari itu, untuk terus bisa mencapai tujuan yang menurut PT Patra Bangun Properti dapat dicapai adalah pertama dengan menetapkan tujuan tersebut yang tidak terlalu mudah dan tidak terlalu sulit, lalu dengan memperhitungkan focus, energi, waktu dan sumber daya yang dimiliki.

\section{Model 7 Tujuan Relevan}

Menurut Yemm (2013:37-39) relevan yang dimaksud adalah sebuah target yang mendukung atau selaras dengan target-target lainnya. Dalam hal ini PT Patra Bangun Properti dalam merelevankan media sosial instagram yang dikelola adalah dengan melakukan profiling kepada para netizen yang dimana hal ini sesuai dengan target dan kebutuhan lain yang dimana hal ini sesuai dengan kebutuhan dan target yang diperlukan perusahaan yaitu menjual produk yang ada.

Namun, walaupun PT Patra Bangun Properti melakukan profiling kepada para netizen merupakan hal yang sesuai dengan target dan kebutuhan lain perusahaan, PT Patra Bangun Properti belum melihat lebih lanjut mengenai layak atau tidak, ketepatan waktu dalam merelevansikan media sosial. Dalam hal ini PT Patra Bangun Properti dikatakan belum merelevankan secara maksimal media sosial instagram yang dikelola dengan tujuan perusahaan dikarenakan belum melihat lebih lanjut mengenai kelayakan serta ketepatan waktu.

Maka dari itu, apabila dilihat berasarkan Yemm (2013:37-39) apabila belum melihat lebih lanjut mengenai kelayakan yang ada maka tentunya PT Patra Bangun Properti akan membuat tujuan dan aspek yang satu dan lainnya tidak akan saling mendukung satu sama lain dan menimbulkan konflik sehingga tujuan yang telah ditetapkan tersebut menjadi tidak relevan. Selain itu menurut Frey dan Osterloh (2002:234) yang dimaksud dengan relevan adalah tujuan yang dicapai oleh pegawai yang sesuai dengan bidangnya atau fungsi spesifik mereka yang dimana tentunya PT Patra Bangun Properti melakukan profiling kepada netizen dengan bantuan digital agency Prime 360 yang dimana bertujuan untuk menyesuaikan media 
sosial tersebut dengan konsumen dan merelevankan informasi yang disampaikan. Maka dari itu PT Patra Bangun Properti seharusnya melihat bagaimana kelayakan atau relevansi dari tujuan tersebut kepada para pelaksana.

\section{Model 8 Tujuan yang Diwaktukan}

Menurut Doran (1981) adalah kapan tujuan yang sudah ditetapkan akan dicapai serta menetapkan tujuan yang akan dicapai dalam kurun waktu tertentu. Dalam hal ini PT Patra Bangun Properti memiliki tujuan yang ditetapkan oleh PT Patra Bangun Properti sendiri ini memiliki rentang waktu seperti harus mengunggah selama 8 kali sebulan, meningkatnya engagement atau pengikut dalam waktu sebulan. Hal ini tentunya sudah sesuai dengan pendapat Doran yang dimana harus memberikan secara jelas kapan tujuan tersebut akan dicapai.

Namun ada tujuan yang ingin menjual secepat mungkin masih dapat dikatakan belum dapat sesuai dengan tujuan yang harus dicapai dalam kurun waktu tertentu, walaupun tujuan yang mereka tetapkan adalah untuk menjual secepat mungkin, namun tidak ada batasan waktu yang jelas pada PT Patra Bangun Properti.

Apabila dilihat dari tujuan yang diwaktukan oleh PT Patra Bangun Properti tersebut PT Patra Bangun Properti dapat dikatakan sesuai dengan tujuan yang harus dicapai dalam kurun waktu tertentu. Selain itu Menurut O’Neil dan Conzemius (2006:33), Frey dan Osterloh (2002:234) bahwa tujuan yang terikat waktu ada baiknya PT Patra Bangun Properti memiliki rangkaian waktu yang spesifik dikarenakan apabila tidak ada rangkaian waktu yang jelas tentunya akan membuat PT Patra Bangun Properti kesulitan dalam melihat tujuan tersebut kapan harus tercapai. Selain itu menurut Lawler dan Bilson (2013:85), Yemm (2013:37-39) bahwa seharusnya tujuan tersebut ditetapkan berdasarkan dengan waktu. Maka dari itu, untuk tetap dapat mencapai tujuan tersebut dalam kurun waktu tertentu, PT Patra Bangun Properti tetap harus menentukan batas waktu secara spesifik untuk tujuan yang ingin dicapai tersebut supaya PT Patra Bangun Properti memiliki batasan waktu untuk tujuan yang ingin dicapai.

Setelah tahapan objektif, tahapan selanjutnya adalah strategi. Pada tahapan strategi ini ini terdiri dari saluran dan pesan kunci atau key message. Pada bagian ini, penulis akan memaparkan hasil yang didapat mengenai strategi yang digunakan dalam pengelolaan media sosial instagram PBP. Pada strategi ini terdiri dari dua poin yaitu saluran spesifik dan pesan kunci atau key message.

\section{Model 9 Saluran Spesifik}

Menurut triangulator, Nur-El Ikhsan bahwa saluran yang spesifik tersebut memudahkan para pengelola media sosial menjalankan strategi yang dirancang sebelumnya. Selain itu spesifiknya saluran yang akan digunakan tersebut dapat membantu memaksimalkan strategi tersebut. Selain itu, Triangulator juga berpendapat bahwa Instagram juga merupakan saluran yang tepat apabila dijadikan sebagai media untuk berkomunikasi serta melakukan promosi dan menyebarkan informasi dikarenakan instagram memiliki fitur 
untuk mengunggah gambar yang bisa memuat banyak informasi sekaligus serta memiliki fitur pesan langsung yang bisa digunakan dalam berkomunikasi.

PT Patra Bangun Properti dapat dikatakan sudah tepat dengan menggunakan instagram sebagai saluran spesifik mereka dan sebagai salah satu strategi mereka. Selain itu, memanfaatkan instagram sebagai saluran spesifik merupakan hal yang tepat dalam penetapan strategi mereka, hal ini dikarenakan Baihaki (dalam Judith, 2017) mengatakan bahwa instagram dipakai oleh 54 persen perusahaan dengan brand ternama di dunia. Hal ini juga didukung bahwa berdasarkan Nisrina (2015:129) bahwa pengguna instagram semakin hari semakin bertambah seiringan dengan banyaknya perusahaan yang melakukan kegiatan promosi atau memberikan informasi dalam media sosial tersebut serta didukung data dari Asosiasi Penyelenggara Jaringan Internet Indonesia (APJII) (dalam Zuhri dan Christiani, 2019) pada tahun 2016 bahwa pengguna Instagram khususnya di Indonesia mencapai 400 juta pengguna aktif

\section{Model 10 Pesan Kunci}

Menurut Smith (2013) dalam konsep pesan kunci, pesan yang disebarkan serta terarah harus memuat kejelasan, ringkas, dan dapat dipahami oleh target audience. Pesan kunci yang dimiliki oleh PT Patra Bangun Properti ini adalah "Smart Choice for Your Premium Living" atau "Hunian Strategis Terdekat Dengan Bandara". Dapat dilihat bahwa pesan kunci milik PT Patra Bangun Properti sudah memuat kejelasan, hal ini dapat ditemukan pada pesan kunci yang mereka buat, yaitu dikarenakan pesan kunci tersebut mencerminkan dari perusahaan mereka yang dimana sedang menjual atau mempromosikan produk mereka yang menurut mereka strategis dan dekat dengan bandara. Selain itu pesan kunci mereka juga ringkas hal ini dapat dilihat dari pesan kunci mereka sendiri yaitu "Hunian Strategis Terdekat Dengan Bandara" yang dimana hanya terdiri dari lima kata saja dan tidak menggunakan kalimat yang banyak hanya untuk pesan kunci mereka dikarenakan untuk mencegah tidak efektifnya pesan kunci yang digunakan sehingga mereka menggunakan lima kata tersebut tetapi memiliki kekuatan bahasa dan slogan yang jelas serta mudah diingat oleh siapapun.

Selanjutnya pesan kunci mereka juga mudah dipahami dikarenakan pesan kunci mereka yaitu “Hunian Strategis Terdekat Dengan Bandara” tidak menggunakan kata kata yang sulit serta tidak menggunakan singkatan singkatan yang membuat orang tidak bertanya tanya akan arti dari singkatan yang digunakan oleh PT Patra Bangun Properti.

Selain itu pesan kunci yang digunakan oleh PT Patra Bangun Properti ini tidaklah panjang dikarenakan mereka hanya memiliki lima kata yang dimana setiap kata tersebut bukanlah kata yang mengandung makna ganda melainkan kata yang sudah jelas artinya dari kata yang digunakan tersebut sehingga membuat pesan kunci tersebut mudah dipahami. Maka dapat dilihat bahwa pesan kunci yang dimiliki atau yang digunakan oleh PT Patra Bangun Properti tersebut memiliki kejelasan, ringkas dan mudah dipahami oleh target audiens.

Setelah tahapan strategi, berikutnya adalah taktik. Pada tahapan ini bertujuan untuk mengetahui taktik yang digunakan dalam pengelolaan media sosial yang dilakukan oleh PT Patra Bangun Properti yang dimana pada tahapan taktik ini terdapat empat poin yang 
berdasarkan model PESO yaitu paid, earned, shared, owned. Poin pertama pada taktik adalah Paid Media.

\section{Model 11 Paid Media}

Berikut adalah contoh fitur promote yang digunakan oleh PT Patra Bangun Properti.

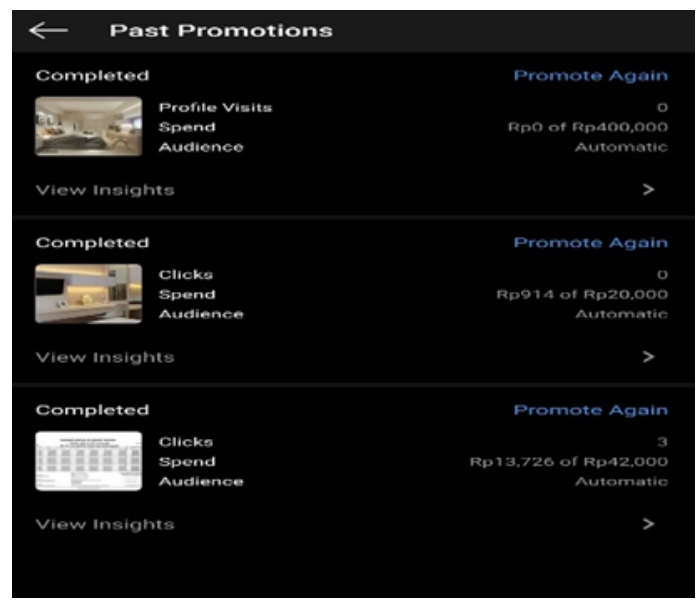

Gambar 1 Promosi yang digunakan oleh PT Patra Bangun Properti dalam media sosial instagram Sumber: Dokumentasi Pribadi 2020

Menurut Luttrell (2018:318) paid media merujuk pada saluran yang dibayar untuk menaikkan atau mengangkat pesan yang ingin disampaikan. Contoh paid media adalah tweet yang di promosikan, iklan yang terdapat pada facebook, iklan bayar per klik, radio, serta sponsor. PT Patra Bangun Properti menggunakan fitur iklan dalam instagram atau lebih sering disebut dengan promote ini menggunakan bayar per klik dan fitur promote ini nantinya akan berbentuk seperti unggahan biasa dan memiliki tautan untuk diklik dan akan menuju ke profil instagram milik PT Patra Bangun Properti yaitu @padinaofficial dan nantinya akan terhitung sebagai bayar per klik dan maka dari itu PT Patra Bangun Properti menggunakan taktik paid media walaupun tidak menggunakan radio atau sponsor.

Menurut Jefkins (1996:230), ada manfaat yang diperoleh dengan penyelenggaraan acara menggunakan sponsorship yaitu dana sponsor yang dikeluarkan dapat kembali dalam jumlah berlipat baik secara langsung maupun tidak langsung. Sedangkan menurut Shimp (2000: 589), Manfaat sponsorship adalah untuk membangun hubungan perusahaan dengan konsumen serta meningkatkan nilai merek dan memperkuat ikatan dalam pertukaran yang dilakukan. Selain itu menurut Cornwell dan Maignan (1998) bahwa melakukan sponsor dengan dua alasan utama yaitu untuk meningkatkan brand awareness serta membangun, memperkuat atau mengubah citra merek sehingga apabila PT Patra Bangun Properti tidak melakukan sponsor tentunya PT Patra Bangun Properti kehilangan kesempatan untuk meningkatkan brand awareness dan kesempatan membangun, memperkuat, atau mengubah citra merek. Maka dari itu, sebaiknya PT Patra Bangun Properti sebaiknya menggunakan taktik sponsorship dengan tujuan dapat menambah nilai merek, serta menguatkan hubungan 
antara konsumen dengan perusahaan dan uang yang dikeluarkan tentunya dapat kembali secara berlipat lipat.

\section{Model 12 Earned Media}

Pada hasil observasi yang didapat oleh peneliti, berikut adalah contoh earned media yang digunakan oleh PT Patra Bangun Properti

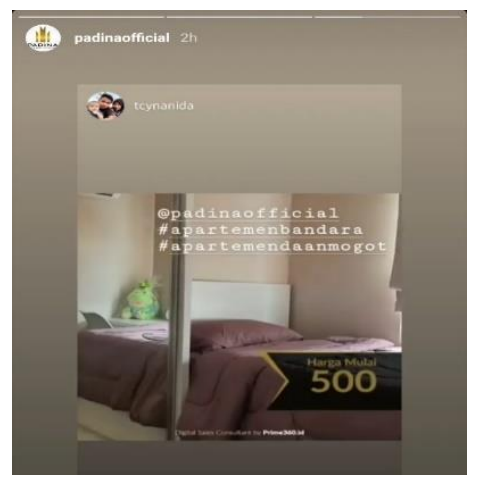

\section{Gambar 2 Contoh Earned media instagram PT Patra Bangun Properti}

Sumber: Dokumentasi Pribadi 2020

Menurut Luttrell (2018:318) earned media adalah pelanggan menjadi saluran bagi perusahaan melalui mulut ke mulut atau pencapaian status viral. PT Patra Bangun Properti secara tidak langsung dapat dikatakan menggunakan earned media dikarenakan PT Patra Bangun Properti tetap membuat konten yang bertujuan untuk diviralkan walaupun para netizen membuat viral dengan tombol suka, komentar dan bagikan tersebut merupakan diluar kehendak PT Patra Bangun Properti.

Secara tidak langsung juga PT Patra Bangun Properti memperoleh suka, komentar serta bagikan pada setiap konten yang mereka unggah pada media sosial mereka serta unggahan pada fitur story mereka yang telah di unggah ulang oleh netizen yang dimana hal itu merupakan langkah PT Patra Bangun Properti untuk mencapai status viral. Dapat diihat bahwa PT Patra Bangun Properti belum sepenuhnya menjalankan taktik earned media ini dikarenakan PT Patra Bangun Properti walaupun sudah membuat konten yang ditujukan untuk di viralkan, akan tetapi semua upaya viral melalui netizen tersebut merupakan diluar kehendak PT Patra Bangun Properti.

Apabila dilihat berdasarkan Luttrell (2018:318), PT Patra Bangun Properti dikarenakan sudah menjalankan taktik earned media walaupun taktik tersebut tetap berjalan diluar kendali PT Patra Bangun Properti sendiri dikarenakan faktor netizen yang memberi suka, komentar dan membagikan, tentunya akan berdampak pada konten yang tidak akan mendapat pada status viral tersebut dikarenakan PT Patra Bangun Properti mengandalkan engagement dari netizen saja yang dimana belum tentu netizen dapat melihat konten yang dibuat oleh PT Patra Bangun Properti. Namun menurut Dietrich (2018) bahwa earned media ini merupakan media yang diperoleh seperti contohnya ketika suatu media memuat informasi mengenai perusahaan yang kita jalankan baik dalam bentuk surat kabar maupun respon dari warganet, sehingga dapat dikatakan bahwa earned media memang media yang tergerak dari luar perusahaan. Maka dari itu berdasarkan bahwa PT Patra Bangun Properti sebaiknya tetap 
membuat konten yang baik supaya dapat diviralkan oleh netizen dikarenakan konten yang menarik netizen dapat mencapai status viral melalui netizen dikarenakan netizen terus menyebarkan konten yang sudah dibuat tersebut. Lalu, juga dibutuhkan engagement dari pihak PT Patra Bangun Properti sendiri untuk membagikan konten yang sudah dibuat tersebut kepada netizen supaya netizen memviralkan konten tersebut dengan membangun hubungan dengan para pegiat media sosial

\section{Model 13 Earned Media}

Menurut Luttrell (2018:318) shared media atau media bersama mengacu pada contoh di mana konsumen bekerja bersama dengan merek untuk membuat, berbagi, dan mempromosikan konten. PT Patra Bangun Properti belum sepenuhnya menggunakan taktik shared media dikarenakan PT Patra Bangun Properti sendiri secara tidak langsung bekerja sama dengan netizen untuk membuat, membagikan serta mempromosikan dikarenakan mereka hanya meminta untuk memberikan testimony mengenai produk PT Patra Bangun Properti yaitu apartemen yang telah mereka beli.

Namun Direktur Utama PT Patra Bangun Properti mengatakan bahwa membuat, membagikan serta mempromosikan konten adalah tugas yang dilakukan oleh pihak internal atau pihak perusahaan saja dan tidak melibatkan netizen atau pelanggan dalam membagika, membuat serta mempromosikan konten. Maka dari itu dapat dilihat bahwa PT Patra Bangun Properti belum sepenuhnya menggunakan taktik shared media dalam pengelolaan media sosial instagram PT Patra Bangun Properti.

Dalam hal ini, menurut Luttrell (2018:318) bahwa PT Patra Bangun Properti apabila tidak menggunakan shared media secara maksimal sebagai salah satu taktik dalam mengelola media sosial instagram, maka PT Patra Bangun Properti tentunya akan menyianyiakan kesempatan untuk bekerja sama dengan konsumen maupun netizen dalam membuat, membagikan serta mempromosikan konten dikarenakan hal tersebut tentunya menjadi suatu taktik untuk menguatkan hubungan PT Patra Bangun Properti dengan konsumen. Hal ini didukung oleh Dietrich (2018) yang berpendapat bahwa salah satu menjalankan taktik shared media adalah dengan mengukur efektifitas pegiat media sosial dan netizen yang dilibatkan, dalam hal ini pengguna shared media dapat menggunakan berbagai cara dengan memberikan diskon, alamat situs yang unik, kode diskon dan nomor telepon untuk melihat apakah ada penurunan atau peningkatan pada pengikut di media sosial tersebut. Maka dari itu, PT Patra Bangun Properti seharusnya mengoptimalkan dan memaksimalkan kerjasama dengan netizen atau pegiat media sosial dalam membuat, membagikan dan mempromosikan konten milik PT Patra Bangun Properti itu sendiri sebagai salah satu cara untuk menarik konsumen dan netizen dengan cara tambahan yaitu dengan menggunakan cara pemberian kode diskon, alamat situs yang unik, kode diskon dan nomor telepon yang dicantumkan melalui media sosial guna mengukur dan melihat apakah ada pengurangan atau peningkatan yang terjadi terutama pada pengikut.

\section{Model 14 Owned Media}


PT Patra Bangun Properti ini juga memiliki website atau situs mengenai produk mereka serta facebook yang dikelola tanpa bantuan agensi tersebut dan langsung dikelola oleh PT Patra Bangun Properti sendiri dikarenakan facebook dan situs yang dimiliki oleh PT Patra Bangun Properti tersebut memang tidak dibantu dalam pengelolaannya oleh Prime 360. Menurut Luttrell (2018:319) owned media adalah media yang dimiliki, atau istilah untuk saluran yang dimiliki dan dikendalikan perusahaan. PT Patra Bangun Properti menggunakan taktik owned media, hal ini dikarenakan PT Patra Bangun Properti sendiri dan mengendalikan memiliki media sosial instagram, facebook, dan situs sendiri yang dikelola oleh PT Patra Bangun Properti. Namun taktik owned media ini tidak sepenuhnya tepat dikarenakan walaupun memiliki media sosial instagram, facebook serta situs sendiri yang dikelola oleh PT Patra Bangun Properti tersebut tidak dikelola seutuhnya oleh PT Patra Bangun Properti akan tetapi dibantu oleh agensi yaitu PT Nata Connexindo Digital (Prime 360) dalam pengelolaannya. Selain itu, Menurut Dietrich (2018) bahwa owned media adalah konten yang dimiliki sendiri oleh perusahaan dan di sebarluaskan oleh perusahaan sendiri dan menjawab pertanyaan yang ditujukan pada konten yang telah di sebarluaskan, sementara itu pada PT Patra Bangun Properti memiliki konten sendiri dan konten yang dibuat oleh Prime 360 dengan persetujuan PT Patra Bangun Properti dan PT Patra Bangun Properti tidak sepenuhnya menjawab pertanyaan yang ditujukan pada konten yang sudah diunggah.

Berdasarkan hal diatas dapat dilihat bahwa PT Patra Bangun Properti menggunakan taktik owned media walaupun dapat dikatakan belum sepenuhnya tepat dikarenakan walaupun PT Patra Bangun Properti memiliki media sosial ataupun situs sendiri, mereka tidak sepenuhnya mengelola situs atau media sosial tersebut secara sendiri melainkan bekerja sama dengan agensi Prime 360 terutama dalam pengelolaan media sosial Instagram. Maka dari itu PT Patra Bangun Properti tetap harus mengelola media sosial yang dimiliki yaitu media sosial Instagram dengan menggunakan konten yang sudah dibuat oleh PT Patra Bangun Properti, lalu situs yang dikelola oleh PT Patra Bangun Properti sendiri serta Facebook milik perusahaan sehingga PT Patra Bangun Properti tidak menyerahkan sepenuhnya pengelolaan media sosial maupun situs yang dikelola supaya taktik owned media tetap berjalan.

Selanjutnya adalah tahapan implementasi, biaya dan linimasa. Implementasi, biaya, dan linimasa dalam pengelolaan media sosial yang dilakukan oleh PT Patra Bangun Properti, yang dimana pada tahapan ini memiliki tiga poin yaitu implementasi, biaya dan linimasa.

\section{Model 15 Implementasi}

Triangulator juga berpendapat bahwa implementasi yang dilakukan apabila melalui media sosial instagram ini tentu pasti berujung pada pengunggahan konten konten yang sudah dirancang berdasarkan tahapan atau proses proses sebelumnya. Menurut Munandar dan Tambunan (2018:8) bahwa implementasi merupakan perincian dari taktik yang dimana merupakan tindakan berupa rumusan program kerja yang tertata, menyangkut jenis program serta pelaksana program dan waktu program tersebut. Sehingga dapat dilihat bahwa implementasi pada instagram selain mengunggah konten konten tentu perlu diperhatikan juga mengenai rumusan program kerja dalam pengunggahan konten konten yang 
bersangkutan untuk memaksimalkan implementasi yang dilakukan oleh PT Patra Bangun Properti. Selain itu selain memperhatikan mengenai rumusan program kerja, implementasi menurut Cakranegara dan Susilowati (2017:14) bahwa pada pengawasan implementasi digunakan matriks untuk mempermudah pengawasan implementasi tersebut, matriks yang digunakan ini tidak lain juga untuk membantu melihat apakah ada indikator yang terlewat atau belum terpenuhi sehingga dapat diperbaiki apabila terlewat atau belum terpenuhi dan membantu PT Patra Bangun Properti memaksimalkan implementasi yang dilakukan. Maka dari itu, untuk tetap melakukan implementasi pada rencana yang sudah ditetapkan sebelumnya, PT Patra Bangun Properti tetap melakukan implementasi berdasarkan dari seluruh tahapan yang telah disusun sebelumnya dengan tetap mengunggah konten konten yang didasari oleh dari tahapan sebelumnya pada media sosial instagram yang dikelola oleh PT Patra Bangun Properti itu sendiri, sehingga pada implementasi ini akan terus berjalan dan terus dilaksanakan oleh PT Patra Bangun Properti sendiri dalam melakukan proses implementasi yang didasarkan oleh tahapan tahapan yang telah ditetapkan sebelumnya.

\section{Model 16 Biaya}

Menurut Luttrell (2018:123) biaya yang dikeluarkan harus berdasakan berbagai pertimbangan serta mengalokasikan 10 persen biaya untuk kejadian tak diduga. Dalam hal ini PT Patra Bangun Properti mengeluarkan biaya sekitar 19- 20 juta untuk pengelolaan media sosial instagram yang dilakukan. Akan tetapi dikarenakan yang terjadi di lapangan bisa berubah atau tidak menentu, pengalokasian biaya PT Patra Bangun Properti dari biaya yang sudah ditetapkan sebelumnya bisa berubah sesuai keadaan, namun PT Patra Bangun Properti tidak mengalokasikan biaya yang ada sebanyak 10 persen untuk kejadian tak terduga dan narasumber dari PT Patra Bangun Properti tidak menyebutkan adanya biaya untuk berjaga. $\mathrm{Hal}$ ini tentunya tidak sesuai dengan Luttrell yang mengatakan bahwa perusahaan mengalokasikan sebanyak 10 persen dari biaya yang sudah ditetapkan untuk berjaga.

Namun tentunya apabila tidak mengalokasikan biaya yang ada minimal sebanyak 10 persen untuk biaya tak terduga dari biaya pengelolaan tersebut, maka biaya yang ada tersebut tidak akan bisa digunakan untuk kejadian yang tidak diduga tersebut dan harus menggunakan biaya yang sepenuhnya dialokasikan untuk media sosial atau akan menggunakan biaya yang telah dialokasikan untuk keperluan lainnya dan hal ini tentunya dapat menghambat berjalannya kegiatan yang lainnya terutama kegiatan yang dilakukan oleh PT Patra Bangun Properti dikarenakan apabila terjadi suatu hal yang tidak terduga seperti membutuhkan pengeluaran lebih secara mendadak mereka tentunya akan menggunakan biaya yang sudah dialokasikan untuk keperluan lagi dan mengakibatkan pemborosan pada pengeluaran yang dilakukan. Triangulator juga berpendapat bahwa sebaiknya biaya yang dialokasikan tidak semuanya digunakan kepada pengeluaran media sosial tersebut dikarenakan untuk digunakan dalam kondisi tertentu sewaktu waktu membutuhkan biaya yang telah dialokasikan tersebut sehingga tidak mengambil atau menggunakan biaya pengelolaan media sosial tersebut sepenuhnya. Maka dari itu PT Patra Bangun Properti seharusnya mengalokasikan biaya yang ada minimal sebanyak 10 persen untuk biaya tak 
terduga dikarenakan biaya tersebut merupakan salah satu hal yang penting dikarenakan apabila ada kejadian mendesak yang mengharuskan mereka untuk mengeluarkan biaya yang lebih tersebut, PT Patra Bangun Properti sudah dapat menyiapkan untuk membayar biaya tersebut dengan biaya yang sudah dialokasikan untuk kejadian tidak terduga tersebut sehingga tidak menarik atau menggunakan pengeluaran dari keperluan lain perusahaan.

\section{Model 17 Linimasa}

Jadi dapat dilihat bahwa konten konten yang berada di dalam linimasa akun instagram @padinaofficial milik PT Patra Bangun Properti ini terdiri dari beragam jenis unggahan yang bersifat informative dan untuk promosi, lalu unggahan yang berdasarkan waktu tertentu yaitu yang diunggah pada hari besar nasional atau hari raya keagamaan tertentu, lalu ada yang bersifat situasional atau tidak diduga seperti konten untuk mengucapkan belasungkawa atas wafatnya BJ Habibie, dan ada juga konten yang memuat informasi kemajuan pembangunan yang dilakukan. Menurut Luttrell (2018:211) linimasa atau timeline merupakan kumpulan dari foto, kisah dan pengalaman yang diunggah oleh pengguna atau merek. Dalam hal ini linimasa pada media sosial instagram pada akun @padinaofficial ini sudah memiliki sebanyak 356 unggahan dan pada unggahan tersebut terdiri dari berbagai foto dan video. Konten yang sudah diunggah merupakan konten yang diunggah sendiri oleh PT Patra Bangun Properti sendiri.

Dalam hal ini, linimasa yang dimiliki oleh PT Patra Bangun Properti sudah sesuai dengan Luttrell yang mengatakan bahwa linimasa adalah koleksi dari foto maupun kisah yang diunggah oleh pengguna atau merek tersebut, bahwa PT Patra Bangun Properti sudah memiliki koleksi foto maupun kisah dalam bentuk foto maupun video yang sudah diunggah sendiri oleh PT Patra Bangun Properti ke media sosial instagram PT Patra Bangun Properti pada akun media sosial instagram @padinaofficial. Menurut Triangulator bahwa linimasa yang baik adalah linimasa yang memiliki suatu ciri khas milik perusahaan seperti warna yang digunakan terus menerus, desain yang tidak berlebihan serta memiliki suatu keterkaitan antara konten yang satu dengan yang lainnya sehingga menarik untuk dilihat.

Selanjutnya adalah tahapan terakhir yaitu laporan dan evaluasi.

\section{Model 18 Laporan}

Menurut Luttrell (2018:124) melakukan laporan dan evaluasi pada setiap tahapan dapat mengetahui apakah tujuan yang telah ditetapkan, strategi yang ditetapkan dan taktik tersebut sesuai atau cocok dengan audiens yang ditargetkan. Selai mengetahui apakah tujuan, strategi dan taktik yang ditetapkan sesuai dengan audiens, menurut Keraf (1993:284) bahwa laporan juga merupakan suatu dokumen yang disampaikan atau menyampaikan informasi dalam bentuk fakta fakta yang berujung pada tindakan yang akan diambil. Sejalan dengan Keraf, menurut Parera (1987:284) bahwa laporan pada dasarnya adalah untuk menyampaikan fakta fakta yang nantinya akan berujung pada tindakan. Sedangkan menurut Soegito (2008:10) bahwa laporan berisikan informasi yang sesuai dengan fakta yang 
ditemukan dan didukung oleh data yang lengkap, dan data disusun dengan tujuan untuk dapat dipercaya dan dapat dipahami.

Sehingga apabila laporan yang dilakukan kurang atau belum maksimal tentunya akan berakibat pada ketidaksesuaian tujuan, strategi dan taktik yang digunakan dengan audiens yang ditargetkan. Selain itu tentunya akan menghambat proses pengambilan keputusan dan berpengaruh pada data yang dimana akan menjadi tidak lengkap. Maka dari itu sebaiknya pelaporan yang telah dilakukan oleh PT Patra Bangun Properti tersebut haruslah dilakukan pada setiap tahapan untuk mengetahui apakah audiens yang ditargetkan tersebut dapat sesuai dengan tujuan, strategi yang digunakan serta taktik yang digunakan dan mempermudah pengambilan keputusan dengan menginformasikan fakta fakta dalam bentuk laporan.

\section{Model 19 Evaluasi}

Menurut Luttrell (2018:124) melakukan laporan dan evaluasi pada setiap tahapan dapat mengetahui apakah tujuan yang telah ditetapkan, strategi yang ditetapkan dan taktik tersebut sesuai atau cocok dengan audiens yang ditargetkan, sehingga apabila laporan yang dilakukan kurang atau belum maksimal tentunya akan berakibat pada ketidaksesuaian tujuan, strategi dan taktik yang digunakan dengan audiens yang ditargetkan. Selain untuk mengetahui bahwa taktik, strategi dan tujuan yang ditetapkan tersebut sesuai dengan audiens, Menurut Arikunto (2004:1) evaluasi sendiri adalah untuk menyediakan berbagai informasi yang dibutuhkan atau yang nantinya akan digunakan untuk menentukan kebijakan yang diambil. Selain untuk menyediakan fungsi informasi yang dibutuhkan, Crawford (2000:30) berpendapat evaluasi bertujuan untuk mengetahui tercapainya tujuan yang telah ditetapkan melalui kegiatan yang telah dilaksanakan. Sementara itu, Menurut Umar (2002:36) bahwa evaluasi adalah proses untuk menyajikan informasi sejauh mana kegiatan tersebut dicapai.

Maka dari itu apabila evaluasi yang dilakukan oleh PT Patra Bangun Properti masih belum efektif dikarenakan tidak dilakukan pada setiap tahapan ini dapat mengakibatkan ketidaksesuaian audiens yang ditargetkan dengan tujuan, strategi dan taktik yang digunakan untuk mencapai audiens dengan menggunakan media sosial tersebut. Selain mengakibatkan ketidaksesuaian pada audiens, apabila tidak melakukan evaluasi pada setiap tahapan yang dilakukan maka PT Patra Bangun Properti tidak akan mengetahui atau tidak akan mendapatkan informasi apakah tujuan yang telah ditetapkan sudah tercapai melalui kegiatan yang telah dilakukan serta tidak dapat mengetahui sejauh mana kegiatan tersebut tercapai.

Hal ini juga berdasarkan pendapat triangulator, Triangulator mengatakan bahwa laporan dan evaluasi tentu adalah untuk melihat apakah tujuan, strategi dan taktik yang ditetapkan tersebut berjalan atau tidak dan memang harus dilakukan pada setiap tahapan untuk mencegah menyimpangnya tahapan atau hal yang sebelumnya direncanakan. Maka dari itu PT Patra Bangun Properti harus mengevaluasi pada seluruh tahapan yang dilakukan untuk mencegah ketidaksesuaian audiens yang ditargetkan dengan tujuan, strategi dan taktik yang diterapkan sebelumnya. Selain untuk mencegah ketidaksesuaian dengan audiens, PT 
Patra Bangun Properti juga harus tetap melakukan evaluasi berdasarkan tahapan tahapan yang ada untuk mengetahui informasi yang akan digunakan oleh pengambil keputusan, serta mengetahui kegiatan dan tujuan yang sudah tercapai melalui evaluasi tersebut.

\section{SIMPULAN}

Pengelolaan media sosial instagram milik PT Patra Bangun Properti pada akun @padinaofficial berdasarkan tahapan ROSTIR milik Regina Luttrell. Dalam tahapan riset dan diagnosis oleh PT Patra Bangun Properti menggunakan riset primer dan sekunder. Selain riset primer dan sekunder yang dilakukan, PT Patra Bangun Properti menggunakan analisis SWOT yang dimana analisis SWOT pada faktor internal dan eksternal. Tujuan PT Patra Bangun Properti dalam pengelolaan media sosial instagram terdiri dari SMART atau Specific, Measurable, Attainable, Relevant dan Timely. Tujuan spesifik PT Patra Bangun Properti dalam pengelolaan media sosial ini adalah menggunakan media sosial instagram ini untuk membantu penjualan serta menjadikan instagram ini sebagai media komunikasi. Sementara itu tujuan yang dapat diukur PT Patra Bangun Properti dalam pengelolaan media sosial instagram adalah meningkatnya awareness yang dimana nantinya akan berakibat pada meningkatnya penjualan melalui media sosial yang digunakan.

Pada strategi, PT Patra Bangun Properti menjadikan instagram sebagai saluran khusus atau saluran spesifik yang dimanfaatkan sebagai strategi dalam pengelolaan media sosial yaitu media sosial. Selain itu PT Patra Bangun Properti memiliki pesan kunci yaitu "Hunian Strategis Terdekat Dengan Bandara" atau "Smart choice for your premium business \& living" yang dimana pesan kunci ini dimuat di instagram PT Patra Bangun Properti itu sendiri. Dalam hal ini, strategi yang ditetapkan oleh PT Patra Bangun Properti dapat dikatakan sesuai dan maksimal dikarenakan saluran yang dipilih untuk dimanfaatkan sudah spesifik dan pesan kunci yang digunakan singkat, mudah dimengerti dan jelas. Pada tahapan taktik, PT Patra Bangun Properti menggunakan taktik paid media yaitu dengan menggunakan fitur promote milik instagram yang dimana hal ini juga merupakan bayar per klik. PT Patra Bangun Properti juga menggunakan taktik earned media walaupun taktik ini tidak sepenuhnya dilakukan. Pada implementasi, biaya dan linimasa, PT Patra Banguun Properti melakukan pengimplementasian seluruh tahapan yang dilalui seperti rsiet, tujuan, strategi dan taktik dengan cara mengunggah konten yang sudah disiapkan pada media sosial instagram.

\section{DAFTAR PUSTAKA}

Anwar, Suroyo. (2009). Pemahaman Individu, Observasi, Checklist, Interview, Kuesioner dan Sosiometri. Yogyakarta: Pustaka Pelajar

Arikunto, Suharsimi. (2006). Prosedur Penelitian Suatu Pendekatan Praktik. Jakarta: Rineka Cipta

Baihaki, I. (2012). 54 Persen Brand Ternama Dunia kini Gunakan Instagram sebagai Sarana Marketing. https://www.beritateknologi.com/54-persen-brandternama-dunia-kini-gunakaninstagram-sebagaisarana-marketing/. diakses pada 5 April 2020

Cakranegara, Pandu Adi \& Susilowati, Ety (2017). Analisis Strategi Implementasi Media Sosial (Studi Kasus UKM “XYZ"). 5 April 2019. http://ejournal.president.ac.id/presunivois/index.php/FIRMJOURNAL/article/viewFile/337/193 
Community (Studi Kasus Komunitas Perpustakaan Jalanan Solo @Koperjas). IImu Perpustakaan, Universitas Diponegoro.

https://ejournal3.undip.ac.id/index.php/iip/article/viewFile/22899/20924

Cornwell, T.B. \& Maignan, I. (1998). An International Review of Sponsorship Research. Journal of Advertising. Vol. 21, pp. 1-21

Crawford, John. (2000). Evaluation of Libraries and Information Services (2 ${ }^{\text {nd }}$ Ed.). London: Aslib, the association for information management and information management international

Dietrich, G. (2018). PR pros must embrace the PESO model.

https://spinsucks.com/communication/pr-pros-must-embrace-the-peso model/. Diakses 5 April, 2020

Doran, George T. (1981). There's S.M.A.R.T Way to Write Management's Goals and Objectives. AMA Forum

Dwyer, Judith; Hopwood, Nicole (2010). Management Strategies and Skills. McGraw-Hill

Fahmi, Irham. (2013). Pengantar Manajemen Keuangan. Bandung: Alfabeta

Ferrel, O.C \& D, Harline. (2005). Marketing Strategy. South Western: Thomson Corporation

Frey, Bruno S. \& Osterloh, Margit (2002). Successful Management by Motivation: Balancing Intrinsic and Extrinsic Incentives. Springer

Ikhsan, Nur-El (2020, 15 Maret). Wawancara Pribadi

Jefkins, Frank. (1996). Periklanan, Edisi 3. Jakarta: Erlangga

Judith, Christiany. (2017). Memahami Struktur Jaringan Media Sosial sebagai Cara Strategis

Periklanan di Era Ekonomi Digital. Jurnal Pekommas, Vol. 2 No.1. 99-114

Keraf, Gorys. (1993). Komposisi Sebuah Pengantar Kemahiran Bahasa. Flores: Nusa Indah

Kriyantono, Rachmat. (2014). Teknik Praktik Riset Komunikasi. Jakarta: Kencana

Lawler, John \& Bilson, Andy (2013). Social Work Management and Leadership : Managing Complexity with Creativity. Routledge

Luttrell, Regina. (2018). Social Media; How to Engage, Share, and Connect. Rowman \& Littlefield

Moleong, Lexy J. (2007). Metodologi Penelitian Kualitatif: Bandung: Remaja Rosda Karya

Munandar, Irwan \& Tambunan, Anton Soejarwo. (2018). Penggunaan Media Sosial sebagai Strategi Kehumasan di Kementrian ESDM Melalui Metode SOSTAC. Balai Pendidikan dan Pelatihan Tambang Bawah Tanah. 18.3202

Nisrina, M. (2015). Bisnis Online, Manfaat Media Sosial Dalam Meraup Uang. Yogyakarta: Kobis

Pakuningjati, Anindita Lintang. (2015). Pengelolaan Media Sosial dalam Mewujudkan Good Governance. Skripsi: Universitas Gadjah Mada

Poister, Theodore H. (2008). Measuring Performance in Public and Nonprofit Organizations. John Wiley \& Sons

Parera, Jos Daniel (1987). Menulis Tertib dan Sistematik. Jakarta: Erlangga

Shimp, Terence A. (2000). Periklanan Promosi: Aspek Tambahan Komunikasi Pemasaran Terpadu, edisi ke-5. Jakarta: Erlangga

Smith, Ronald D. (2013). Strategic Planning for Public Relations. New York. Routledge

Soegito, Atmohoetomo (2010). Menjadi Sutradara Televisi: Dengan Single dan Multi Camera. Jakarta: Grasindo

Sugiyono. (2012). Metode Penelitian Kuantitatif, Kualitatif, dan R\&D Bandung: Alfabeta

Umar, Husein. (2002). Evaluasi Kinerja Perusahaan. Jakarta: Gramedia Pustaka Utama

Yemm, Graham (2013). Essential Guide to Leading Your Team: How to Set Goals, Measure Performance and Reward Talent: Pearson Education

Zuhri, M. Abdul Malik \& Christiani, Lidya (2019). 5 April, 2020. Pemanfaatan Media Sosial Instagram Sebagai Media Promosi Library Based 